University of Montana

ScholarWorks at University of Montana

$10-2010$

\title{
Interactive Effects of Historical Logging and Fire Exclusion on Ponderosa Pine Forest Structure in the Northern Rockies
}

\author{
Naficy Cameron \\ Anna Sala \\ University of Montana - Missoula, sala@mso.umt.edu \\ Eric G. Keeling \\ Jon Graham \\ Thomas H. DeLuca
}

Follow this and additional works at: https://scholarworks.umt.edu/biosci_pubs

Part of the Biology Commons

Let us know how access to this document benefits you.

\section{Recommended Citation}

Cameron, Naficy; Sala, Anna; Keeling, Eric G.; Graham, Jon; and DeLuca, Thomas H., "Interactive Effects of Historical Logging and Fire Exclusion on Ponderosa Pine Forest Structure in the Northern Rockies" (2010). Biological Sciences Faculty Publications. 15.

https://scholarworks.umt.edu/biosci_pubs/15

This Article is brought to you for free and open access by the Biological Sciences at ScholarWorks at University of Montana. It has been accepted for inclusion in Biological Sciences Faculty Publications by an authorized administrator of ScholarWorks at University of Montana. For more information, please contact scholarworks@mso.umt.edu. 


\title{
Interactive effects of historical logging and fire exclusion on ponderosa pine forest structure in the northern Rockies
}

\author{
Cameron Naficy, ${ }^{1}$ Anna Sala,${ }^{1,4}$ Eric G. Keeling,,${ }^{1}$ Jon Graham, ${ }^{2}$ and Thomas H. Deluca ${ }^{3,5}$ \\ ${ }^{1}$ Division of Biological Sciences, The University of Montana, Missoula, Montana 59812 USA \\ ${ }^{2}$ Department of Mathematical Sciences, The University of Montana, Missoula, Montana 59812 USA \\ ${ }^{3}$ The Wilderness Society, 503 West Mendenhall, Bozeman, Montana 59715 USA
}

\begin{abstract}
Increased forest density resulting from decades of fire exclusion is often perceived as the leading cause of historically aberrant, severe, contemporary wildfires and insect outbreaks documented in some fire-prone forests of the western United States. Based on this notion, current U.S. forest policy directs managers to reduce stand density and restore historical conditions in fire-excluded forests to help minimize high-severity disturbances. Historical logging, however, has also caused widespread change in forest vegetation conditions, but its long-term effects on vegetation structure and composition have never been adequately quantified. We document that fire-excluded ponderosa pine forests of the northern Rocky Mountains logged prior to 1960 have much higher average stand density, greater homogeneity of stand structure, more standing dead trees and increased abundance of fire-intolerant trees than paired fire-excluded, unlogged counterparts. Notably, the magnitude of the interactive effect of fire exclusion and historical logging substantially exceeds the effects of fire exclusion alone. These differences suggest that historically logged sites are more prone to severe wildfires and insect outbreaks than unlogged, fire-excluded forests and should be considered a high priority for fuels reduction treatments. Furthermore, we propose that ponderosa pine forests with these distinct management histories likely require distinct restoration approaches. We also highlight potential long-term risks of mechanical stand manipulation in unlogged forests and emphasize the need for a long-term view of fuels management.
\end{abstract}

Key words: Douglas-fir; fire exclusion; fire suppression; fuel reduction; historical conditions; logging; northern Rockies; ponderosa pine; reference conditions; restoration; timber harvest.

\section{INTRODUCTION}

Many contemporary semiarid forests of western North America have been greatly altered since Euro-American settlement (Veblen and Lorenz 1986, Minnich et al. 1995, Hessburg et al. 2000, Kaufmann et al. 2000, Fulé et al. 2002, Baker et al. 2007). These forests are frequently more homogeneous and structurally simplified, with higher average density and a greater proportion of ladder fuels and shade-tolerant trees, but with fewer large trees and old growth stands than historical forests. While many causes have been invoked to explain these changes the active suppression of fire since the early 1900s has been the most widely studied and cited (Arno et al. 1995, Minnich et al. 1995, Fulé et al. 2002, Keeling et al. 2006). However, widespread logging in western North American forests has predated effective fire suppression by many decades and has affected a majority of semiarid

Manuscript received 6 February 2009; revised 4 September 2009; accepted 17 November 2009; final version received 10 December 2009. Corresponding Editor: B. McKenzie.

${ }^{4}$ Corresponding author; E-mail: sala@mso.umt.edu

${ }^{5}$ Present address: Second Floor ECW, School of the Environment, Natural Resources and Geography, Bangor University, Gwynedd LL57 2UW United Kingdom. forests (Veblen and Lorenz 1986, Habeck 1988, Minnich et al. 1995, Kaufmann et al. 2000, Hessburg and Agee 2003, Baker et al. 2007). Despite the recognition that a variety of historical logging practices have resulted in a substantial lack of large trees and subsequent ingrowth of smaller diameter, less fire-tolerant trees (Gruell et al. 1982, Habeck 1988, 1990, Smith and Arno 1999, Allen et al. 2002, Hessburg and Agee 2003, Brown et al. 2004, Baker et al. 2007) the magnitude and importance of these influences on long-term stand dynamics and contemporary forest conditions is largely unknown. Therefore, we have very limited quantitative understanding of the extent to which historical logging has contributed to increased stand density and other shifts in forest structure and composition that are associated with uncharacteristically severe disturbances in some contemporary forests. As a result, the long-term effects of logging and fire exclusion are often conflated.

The lack of quantitative data on long-term effects of historical logging has led to an emphasis in the scientific literature on fire exclusion effects over those of logging (Arno and Brown 1989, Bonnicksen 1989, Covington 2000, Graham et al. 2004, Savage and Mast 2005) and to the common perception of the public and policy makers that increased forest density is primarily the result of 
decades of fire exclusion alone. Based on this perception major federal forest policies have been enacted to hasten treatment in fire-excluded forests, as a method of reducing severe wildfires and insect outbreaks (Ten Year Comprehensive Strategy 2001, White House 2002, HFRA 2003). However, multiple anthropogenic disturbances can produce novel, non-additive responses in biological systems (Paine et al. 1998). Therefore, distinct forest management histories may necessitate unique restoration and fuel reduction priorities, goals, prescriptions, and measures of success (Kauffman 2004).

Circumstantial data suggest that logging may have contributed to increased stand density and abundance of fire-intolerant species above those caused by fire exclusion alone (Minnich et al. 1995, Kaufman et al. 2000). These studies, though, were either not designed to test the relative effects of logging and fire exclusion or were not well replicated. If logging causes increases of stand density above those created by fire exclusion alone, the magnitude and nature of departures from reference conditions that have occurred during the active fire suppression period may differ in logged vs. unlogged forests. An important question, then, is whether the logging effect is quantitatively significant relative to the effects of fire exclusion alone. Here, we address this question by (1) assessing whether historical logging has contributed to contemporary forest structural attributes similar to those ascribed to fire exclusion alone and (2) quantifying the relative magnitude of departures caused by fire exclusion with and without historical logging.

To test the relative effects and magnitude of distinct land management histories, we first compare forest structure and composition in historically logged, fireexcluded sites with paired unlogged, fire-excluded sites in ponderosa pine/Douglas-fir forests of the Northern Rocky Mountains, USA. We then contrast our data with that of Keeling et al. (2006), who quantified the effects of fire exclusion alone in ponderosa pine/ Douglas-fir forests within our same study region. Our combined data sets allow comparison of stand structure and composition in unlogged, fire-excluded and logged, fire-excluded stands relative to contemporary unlogged, fire-maintained stands which we use as a reference baseline to quantify management-induced changes in forest characteristics.

\section{Materials and Methods}

\section{Study area}

Our study area encompasses a broad geographic region within the northern Rockies, extending across the Continental Divide from the island mountain ranges in central Montana west into central Idaho (Fig. 1). Within our study region, ponderosa pine is a dominant cover type in low and some middle elevation forests across a range of habitat types (Pfister et al. 1977, Steele et al. 1981). Fire regimes in ponderosa pine/Douglas-fir forests of the northern Rockies region include low- and mixed-severity regimes (Brown et al. 1994, Arno et al.
1995, 2000, Baker et al. 2007, Hessburg et al. 2007). Beginning in the late 1800 s to early 1900 s, many forests experienced a punctuated decline in fire frequency generally associated with a shift toward cooler spring and summer climate (Morgan et al. 2008) combined with expanding Euro-American settlement and fire suppression efforts in subsequent decades (Arno et al. 1995). Prior to the early 1960s, timber harvest in the northern Rockies was largely focused on high grade and individual selection harvest methods, with occasional group selection harvests (Gruell et al. 1982, Smith and Arno 1999, Hessburg and Agee 2003). Logging prescriptions generally favored removal of many of the largest and some of the medium-sized ponderosa pine as well the majority of all other species (see Gruell et al. 1982, Smith and Arno 1999). Residual stands generally retained some large and many medium sized ponderosa pine trees, although substantial variation existed in postharvest stand structure. Logging and fire suppression histories exhibit significant spatial overlap and have affected a substantial portion of the ponderosa pine/ Douglas-fir forest in the region (Arno et al. 1995, Hessburg et al. 2000, Hessburg and Agee 2003, Baker et al. 2007).

\section{Sampling design}

We used a paired design of logged, fire-excluded stands (referred to as logged) with unlogged, fire-excluded stands (referred to as unlogged) to quantify changes in forest structure and composition associated with each management scenario while controlling for unrelated, confounding factors. A coarse analysis of potential watersheds for sampling was conducted using spatial data layers of vegetation and disturbance history (logging and fire) and through consultation with Forest Service silviculturists and fire management staff. Logging history coverages generally extended back to the 1950s. Information on historical logging predating the 1950s was collected from local Forest Service staff and was used to supplement spatial data layers to identify watersheds with patchy historical timber harvest. We did not collect detailed fire history data for our sites and instead relied on fire history atlases extending back to 1940 . Based on the fire atlases, we define fire-excluded sites for the purposes of this study as those not burned since at least the 1940s. Fire history studies in ponderosa pine forests of our region report average fire-free intervals of approximately 7-52 years, with an overall cross-study average of 20 years (Habeck 1990, Brown et al. 1994, Arno et al. 1995, 1997). Therefore, the minimum 65 -year fire-free threshold for our sample sites (derived from fire atlases extending back to 1940) is sufficient to represent fire exclusion effects. Furthermore, studies in the immediate vicinity of many of our sample sites date the last wildfire to the mid 1800s through early 1900s (Arno et al. 1995, Heyerdahl et al. 2008) suggesting that the 65-year fire-free threshold most likely underestimates the true fire-free interval by many decades. While a small number of our 


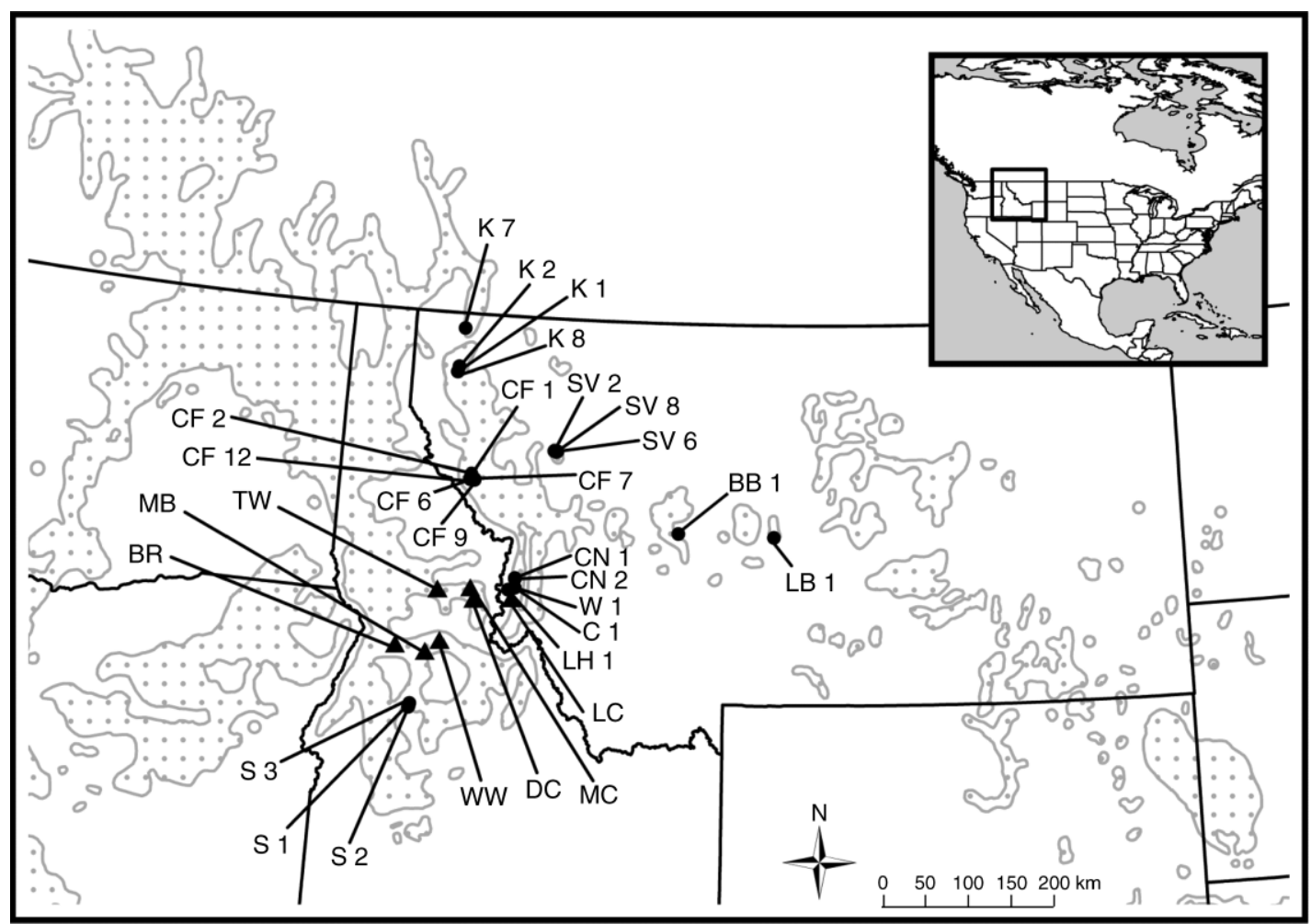

FIG. 1. Map of the study region showing sample sites from this paper (solid circles) and from Keeling et al. (2006; solid triangles) in Montana and Idaho, USA. Stippled areas represent distribution of ponderosa pine forest based on USGS (1999) digitized maps. Sites from this study include: BB, Big Belts; C, Camas; CN, Canyon; CF, Clark Fork; K, Koocanusa; LB, Little Belts; LH, Lost Horse; S, Salmon; SV, Swan Valley; W, Ward. Sites used in the subset analysis are C, CN, LH, S, and W. Sites from Keeling et al. (2006) include: BR, Bullion Ridge; MB, Mackay Bar; TW, 23 Mile; LC, Lake Como; MC, Moose Creek; DC, Ditch Creek; WW, Whitewater Ranch.

sample sites likely pertain to variable- or mixed-severity fire regimes which commonly experience long fire-free intervals (Arno et al. 2000, Baker et al. 2007, Hessburg et al. 2007, Sherriff and Veblen 2007) and may therefore not be outside the range of historically observed fire-free intervals, of importance for this paper is that even in these stands, changes in stand structure and composition consistent with the effects of fire exclusion have still occurred due to natural succession in the absence of fire since at least 1940 .

Extensive field surveys were conducted during the summer of 2006 in the initially selected watersheds to identify and select specific suitable paired stands. Site selection criteria included: no known grazing history, lack of fire since 1940, a single logging event no more recent than 40 years old, no tree planting following logging, close proximity of paired stands, and similarity of soil types and other physiographic parameters between them. All sites were surveyed for signs of recent grazing or fire, for the presence of old stumps in logged sites and the absence of stumps or other signs of previous harvest in unlogged stands, and for the presence of suitable pairs within the same historical stand or in neighboring stands with similar physiographic characteristics. Although fire atlases have limited accuracy with respect to smaller and older fires and do not account for unburned areas within a fire perimeter, in all cases our field surveys corroborated the fire atlas information indicating a lack of fires since the early 20 th century. All of our stands had no evidence of past high-severity fire (i.e., fire-killed patches, single-aged cohorts), and all the unlogged stands were uneven-aged old growth, where many trees had fire scars and other evidence of past lowseverity fire. Therefore, it is likely that all of our study sites historically experienced repeated low-severity fires. This interpretation is corroborated by fire history data in our region, including those found in areas thought to be characterized by variable-severity fire regimes (Arno et al. 1995, Heyerdahl et al. 2008). Paired sites were selected such that unlogged and logged sites prior to harvest exhibited old growth, or mature, stand characteristics, with similar numbers and sizes of large trees. Due to natural topographic variation, patchy disturbance history, and natural heterogeneity of old growth forest conditions, the aerial coverage of sample stands varied substantially. Differences in pre-logging stand structure between paired sites were evaluated post-sampling (see Preharvest stand structure and logging reconstruction).

In logged sites, the relative decay of stumps was visually assessed to determine whether multiple entries 
TABLE 1. Sample site names, physiographic information for individual sites, and overall averages for logged and unlogged treatments.

\begin{tabular}{|c|c|c|c|c|c|}
\hline Site name & National Forest & Elevation (m) & Aspect (degrees) & Slope (degrees) & $\Delta$ distance $(\mathrm{km}) \dagger$ \\
\hline$\overline{\text { Camas } 1 \ddagger}$ & Bitterroot & & & & \\
\hline $\begin{array}{l}\text { Logged } \\
\text { Unlogged }\end{array}$ & & $\begin{array}{l}1570.73 \\
1606.10\end{array}$ & $\begin{array}{l}140 \\
144\end{array}$ & $\begin{array}{l}20 \\
20\end{array}$ & 0.04 \\
\hline Canyon $1 \ddagger$ & Bitterroot & & & & \\
\hline $\begin{array}{l}\text { Logged } \\
\text { Unlogged }\end{array}$ & & $\begin{array}{l}1556.40 \\
1542.68\end{array}$ & $\begin{array}{l}82 \\
79\end{array}$ & $\begin{array}{r}9 \\
11\end{array}$ & 0.06 \\
\hline Canyon $2 \ddagger$ & Bitterroot & & & & \\
\hline $\begin{array}{l}\text { Logged } \\
\text { Unlogged }\end{array}$ & & $\begin{array}{l}1733.84 \\
1753.35\end{array}$ & $\begin{array}{l}82 \\
76\end{array}$ & $\begin{array}{l}23 \\
22\end{array}$ & 0.04 \\
\hline Lost Horse $1 \ddagger$ & Bitterroot & & & & \\
\hline $\begin{array}{l}\text { Logged } \\
\text { Unlogged }\end{array}$ & & $\begin{array}{l}1436.89 \\
1406.10\end{array}$ & $\begin{array}{l}187 \\
176\end{array}$ & $\begin{array}{l}11 \\
15\end{array}$ & 0.16 \\
\hline Ward $1 \ddagger$ & Bitterroot & & & & \\
\hline $\begin{array}{l}\text { Logged } \\
\text { Unlogged }\end{array}$ & & $\begin{array}{l}1617.38 \\
1620.43\end{array}$ & $\begin{array}{l}131 \\
142\end{array}$ & $\begin{array}{l}19 \\
13\end{array}$ & 0.10 \\
\hline Swan Valley 2 & Flathead & & & & \\
\hline $\begin{array}{l}\text { Logged } \\
\text { Unlogged }\end{array}$ & & $\begin{array}{l}1122.26 \\
1108.23\end{array}$ & $\begin{array}{l}219 \\
314\end{array}$ & $\begin{array}{l}2 \\
1\end{array}$ & 0.10 \\
\hline Swan Valley 6 & Flathead & & & & \\
\hline $\begin{array}{l}\text { Logged } \\
\text { Unlogged }\end{array}$ & & $\begin{array}{l}1256.40 \\
1249.09\end{array}$ & $\begin{array}{l}199 \\
234\end{array}$ & $\begin{array}{l}9 \\
8\end{array}$ & 0.22 \\
\hline Swan Valley 8 & Flathead & & & & \\
\hline $\begin{array}{l}\text { Logged } \\
\text { Unlogged }\end{array}$ & & $\begin{array}{l}1155.18 \\
1150.91\end{array}$ & $\begin{array}{r}2 \\
18\end{array}$ & $\begin{array}{l}5 \\
1\end{array}$ & 6.07 \\
\hline Big Belts 1 & Helena & & & & \\
\hline $\begin{array}{l}\text { Logged } \\
\text { Unlogged }\end{array}$ & & $\begin{array}{l}1375.30 \\
1415.85\end{array}$ & $\begin{array}{l}165 \\
156\end{array}$ & $\begin{array}{l}10 \\
17\end{array}$ & 0.23 \\
\hline Koocanusa 1 & Kootenai & & & & \\
\hline $\begin{array}{l}\text { Logged } \\
\text { Unlogged }\end{array}$ & & $\begin{array}{l}967.68 \\
980.79\end{array}$ & $\begin{array}{l}228 \\
222\end{array}$ & $\begin{array}{l}16 \\
20\end{array}$ & 0.04 \\
\hline Koocanusa 2 & Kootenai & & & & \\
\hline $\begin{array}{l}\text { Logged } \\
\text { Unlogged }\end{array}$ & & $\begin{array}{r}945.73 \\
1022.56\end{array}$ & $\begin{array}{l}153 \\
144\end{array}$ & $\begin{array}{l}24 \\
31\end{array}$ & 0.28 \\
\hline Koocanusa 7 & Kootenai & & & & \\
\hline $\begin{array}{l}\text { Logged } \\
\text { Unlogged }\end{array}$ & & $\begin{array}{l}1035.37 \\
1039.94\end{array}$ & $\begin{array}{l}173 \\
185\end{array}$ & $\begin{array}{l}17 \\
22\end{array}$ & 0.11 \\
\hline Koocanusa 8 & Kootenai & & & & \\
\hline $\begin{array}{l}\text { Logged } \\
\text { Unlogged }\end{array}$ & & $\begin{array}{l}1086.28 \\
1079.27\end{array}$ & $\begin{array}{l}229 \\
203\end{array}$ & $\begin{array}{l}13 \\
16\end{array}$ & 0.28 \\
\hline Little Belts 1 & Lewis and Clark & & & & \\
\hline $\begin{array}{l}\text { Logged } \\
\text { Unlogged }\end{array}$ & & $\begin{array}{l}1658.54 \\
1693.90\end{array}$ & $\begin{array}{l}194 \\
200\end{array}$ & $\begin{array}{l}34 \\
33\end{array}$ & 0.07 \\
\hline Clark Fork 1 & Lolo & & & & \\
\hline $\begin{array}{l}\text { Logged } \\
\text { Unlogged }\end{array}$ & & $\begin{array}{l}1145.12 \\
1247.87\end{array}$ & $\begin{array}{l}242 \\
255\end{array}$ & $\begin{array}{l}29 \\
24\end{array}$ & 0.27 \\
\hline Clark Fork 2 & Lolo & & & & \\
\hline $\begin{array}{l}\text { Logged } \\
\text { Unlogged }\end{array}$ & & $\begin{array}{l}1375.00 \\
1296.95\end{array}$ & $\begin{array}{l}173 \\
170\end{array}$ & $\begin{array}{l}30 \\
32\end{array}$ & 0.12 \\
\hline Clark Fork 6 & Lolo & & & & \\
\hline $\begin{array}{l}\text { Logged } \\
\text { Unlogged }\end{array}$ & & $\begin{array}{l}1048.78 \\
1075.61\end{array}$ & $\begin{array}{l}210 \\
197\end{array}$ & $\begin{array}{l}29 \\
30\end{array}$ & 0.04 \\
\hline Clark Fork 7 & Lolo & & & & \\
\hline $\begin{array}{l}\text { Logged } \\
\text { Unlogged }\end{array}$ & & $\begin{array}{l}1161.59 \\
1230.79\end{array}$ & $\begin{array}{l}173 \\
151\end{array}$ & $\begin{array}{l}28 \\
31\end{array}$ & 0.22 \\
\hline Clark Fork 9 & Lolo & & & & \\
\hline $\begin{array}{l}\text { Logged } \\
\text { Unlogged }\end{array}$ & & $\begin{array}{l}1246.34 \\
1239.02\end{array}$ & $\begin{array}{l}64 \\
39\end{array}$ & $\begin{array}{l}20 \\
17\end{array}$ & 0.08 \\
\hline
\end{tabular}


TABle 1. Continued.

\begin{tabular}{|c|c|c|c|c|c|}
\hline Site name & National Forest & Elevation $(\mathrm{m})$ & Aspect (degrees) & Slope (degrees) & $\Delta$ distance $(\mathrm{km}) \dagger$ \\
\hline Clark Fork 12 & Lolo & & & & \multirow[b]{2}{*}{0.26} \\
\hline $\begin{array}{l}\text { Logged } \\
\text { Unlogged }\end{array}$ & & $\begin{array}{l}1142.99 \\
1148.78\end{array}$ & $\begin{array}{l}240 \\
252\end{array}$ & $\begin{array}{l}22 \\
21\end{array}$ & \\
\hline Salmon $1 \ddagger$ & Payette & & & & \\
\hline $\begin{array}{l}\text { Logged } \\
\text { Unlogged }\end{array}$ & & $\begin{array}{l}1297.56 \\
1291.46\end{array}$ & $\begin{array}{l}267 \\
271\end{array}$ & $\begin{array}{l}24 \\
27\end{array}$ & 0.31 \\
\hline Salmon $2 \ddagger$ & Payette & & & & \\
\hline $\begin{array}{l}\text { Logged } \\
\text { Unlogged }\end{array}$ & & $\begin{array}{l}1417.99 \\
1395.73\end{array}$ & $\begin{array}{l}260 \\
249\end{array}$ & $\begin{array}{l}23 \\
26\end{array}$ & 21.24 \\
\hline Salmon $3 \ddagger$ & Payette & & & & \multirow[b]{2}{*}{0.05} \\
\hline $\begin{array}{l}\text { Logged } \\
\text { Unlogged }\end{array}$ & & $\begin{array}{l}1345.43 \\
1330.18\end{array}$ & $\begin{array}{l}284 \\
284\end{array}$ & $\begin{array}{l}14 \\
10\end{array}$ & \\
\hline \multicolumn{6}{|c|}{ Treatment averages } \\
\hline $\begin{array}{l}\text { Logged } \\
\text { Unlogged }\end{array}$ & & $\begin{array}{l}1291.25 \\
1301.11\end{array}$ & $\begin{array}{l}178 \\
181\end{array}$ & $\begin{array}{l}19 \\
19\end{array}$ & 1.32 \\
\hline \multicolumn{6}{|c|}{$\begin{array}{l}\text { Keeling et al. (2006) } \\
\text { site averages }\end{array}$} \\
\hline $\begin{array}{l}\text { Burned } \\
\text { Unlogged }\end{array}$ & & $\begin{array}{l}1214.17 \\
1346.17\end{array}$ & $\begin{array}{l}188 \\
210\end{array}$ & $\begin{array}{l}33 \\
28\end{array}$ & \\
\hline
\end{tabular}

Note: The distance between paired sites is " $\Delta$ distance."

$\dagger$ Note that distance differences are aerial estimates that do not account for terrain. Actual site differences may have been somewhat larger.

\$ Sites used in the subsample comparisons with sites from Keeling et al. (2006). Average physiographic information is also provided for the sites sampled in Keeling et al. (2006).

had occurred. All stumps observed within and around a sample site were inspected for signs of substantially different states of decay based on the presence and quantity of remaining bark, total amount of bole degradation, and the amount of sapwood decay. Stands were also surveyed for evidence of distinct harvest techniques, indicating possible multiple entries. If sites with stumps of similar species and diameter classes exhibited distinct phases of visual decay, or if uncertainties existed, they were discarded. Otherwise, sites were considered to have experienced only one logging entry and were eligible for sampling. We cannot account for cutting of small trees that may have accompanied harvest of larger trees but whose stumps have fully decomposed. Approximate harvest dates in our sites estimated from historical accounts ranged from the early 1890 s to the early 1960 s, although most of our logged sites were harvested in the early 1900s.

Once suitable paired sites had been identified and selected according to the above criteria, a rough boundary for each logged and unlogged stand was delineated using maps and ground surveys of the area. Sampling plot locations within each treatment area were placed a random distance $(0-60 \mathrm{~m})$ and direction $(0-$ $360^{\circ}$ ) from the area's center. If a plot center was located such that part of it extended outside the treatment area (i.e., logged or unlogged area) or if the plot boundary lay closer than $50 \mathrm{~m}$ to the treatment area boundary, subsequent random distance, and direction readings were made until these criteria were met. Within each stand, one $20 \times 50 \mathrm{~m}$ (0.1-ha) plot was placed around plot center with its long axis perpendicular to the slope. Physiographic site variables including slope, aspect, and elevation were recorded at plot center. Within each plot, the diameter at breast height ( $\mathrm{dbh}$ ) of all trees $\geq 4 \mathrm{~cm}$ $\mathrm{dbh}$ and the dbh of dead trees and stumps were measured and recorded by species. Stump diameter was measured at the highest point where an accurate diameter measurement could be taken, and the height above ground level for each stump diameter measurement was also recorded. In total, we sampled 46 stands (23 pairs) of low to mid elevation (mean $=1296 \mathrm{~m}$, range $=946-1753 \mathrm{~m}$ ) pure and mixed ponderosa pine forests (Fig. 1, Table 1).

\section{Preharvest stand structure and logging reconstruction}

Because we could not obtain detailed records of the specific logging type at our sites, we used stump evidence and dendrochronology-based stand reconstruction of pre-logging stand structure to provide an estimate of the basal area (BA) harvested from each stand. For each tree species present within a logged site, we extracted increment cores from nine trees spanning the range of diameter sizes found within that site. In cases where fewer than nine trees of a given species were present in a plot, the total number of cores extracted for that species was equal to the number of individuals of a species within that plot. Increment cores were extracted at breast height and processed in the lab according to standard methods (Stokes and Smiley 1968). For each core, tree rings were counted to establish minimum tree age. Age corrections for core extraction height were 
estimated from two to three contemporary young trees of breast height within each sample stand. Missed rings for cores that did not contain the pith were estimated using the height and length of the last incomplete ring to measure the distance to the pith, divided by the average ring width of the last three complete inner rings.

Linear regressions were used to construct an age-dbh relationship for each tree species at each site. On average, tree-age- $\mathrm{dbh}$ relationships estimated from increment cores explained $68 \%$ of the variation in the data. Using these age-dbh relationships, we estimated the current age of all trees within contemporary logged sites and backcast the dbh of each tree to its age at the time of the logging event. In the absence of specific logging dates for each site, we backcast all trees to 1940 , an approximate average date of logging for all of our sites. In a small number of sites where too few individuals of tree species other than Douglas-fir and ponderosa pine existed to construct a reliable age-dbh regression, we used an average species-specific age-dbh relationship derived from data pooled across all sites. Trees estimated to have established after the logging date were not included in the pre-logging stand reconstruction. The backcast $\mathrm{dbh}$ of all remaining trees was combined with corrected stump dbh values and used to estimate the pre-logging stand BA and density of logged sites. Stump diameter measurements were converted to $\mathrm{DBH}$ estimates using a best fit regression equation (power curve; $R^{2}=68 \%$ ) constructed from diameter vs. height above ground measurements from large living ponderosa pine trees within our sites $(n=30$ trees). The percentage of BA harvested was then calculated as the stump BA divided by stump BA added to the backcast stand BA.

To corroborate field-based assessments of similarity in pre-logging stand density and BA between logged and unlogged sites, we also backcast stand structure in unlogged sites to the date of harvest in logged stands (see Statistics). For a subsample of our sites $(n=7$ paired sites) for which cores from trees $\geq 40 \mathrm{~cm}$ dbh where available from both logged and unlogged sites, we found little difference in the age-dbh relationship of logged and unlogged sites (data not shown) suggesting that potential logging release effects were later offset by increases in density (see Results). Therefore, we used regression equations derived from cores for each site's logged pair to backcast BA and density in unlogged stands. Such estimates, however, are very coarse and are given only to complement our field-based assessment.

\section{Comparison with fire exclusion effects}

The paucity of fire-maintained stands outside wilderness or remote areas precluded a fully factorial comparison of paired frequently burned and unburned stands both with and without logging. Instead, we combined our data set with that of Keeling et al. (2006), who quantified fire exclusion effects in ponderosa pine forests of the northern Rocky Mountains by pairing unlogged stands subjected to two to four fires in the 20th century (referred to as "burned" stands) with unlogged stands not burned for at least 74 years. The combined data set provides a unique comparison of stand attributes across unlogged, fire-maintained stands, and both logged and unlogged fire-excluded stands. In order to match the sampling design of Keeling et al. (2006) we include only trees $\geq 5 \mathrm{~cm} \mathrm{dbh}$ in the combined data set analysis. Stands from Keeling et al. (2006) encompassed a smaller geographic area of western Montana and north-central Idaho than our study (Fig. 1). To ensure the validity of combining the two data sets, we tested whether fireexcluded, unlogged sites from both studies were similar (see Statistics section) and we compared results using the whole data set from our study $(n=23)$ with those using only a subset $(n=8)$ of our sites nearby the areas studied by Keeling et al. (2006) (Fig. 1, Table 1).

\section{Statistics}

Paired $t$-tests were used to evaluate statistical differences between logged and unlogged stands for plot elevation, slope, aspect, total stand density, total stand $\mathrm{BA}$, and large tree age. We used a multivariate linear model (MANOVA) to test for omnibus differences (i.e., at all factor levels) in the distribution of paired differences of tree density and BA across four size classes: $4-20 \mathrm{~cm}, 20-40 \mathrm{~cm}, 40-60 \mathrm{~cm}$, and $>60 \mathrm{~cm}$ and four tree groups: ponderosa pine, Douglas-fir, all species pooled, and snags. Based on the outcome of this test, we used paired $t$ tests in a post hoc framework for all normally distributed data, to identify within pair differences between logged and unlogged sites for each size class and tree group combination. Normality was assessed through visual inspection of the data and with Kolmogrov-Smirnov goodness of fit tests. When necessary, natural $\log$ transformations were used to meet normality requirements. Nonparametric Wilcoxon signed rank tests were used to assess differences in BA and density where data did not meet normality requirements. A similar process was used to test for differences in total stand BA and density between size classes for backcast logged and unlogged sites.

We used the sequential Bonferroni technique (Rice 1989) to account for multiple comparisons of density and BA between the four size classes and the three independent tree groups (ponderosa pine, Douglas-fir, and snags), with separate corrections made for pooled size classes and tree groups. Using this method, $\alpha$-level adjustments were made separately for density and BA for all tree-group-size-class combinations for ponderosa pine, Douglas-fir, and snags (initial correction, $\alpha / 12$ ), for the remaining tree group (i.e., all species pooled) by size class (initial correction, $\alpha / 4$ ), and for all size classes combined for the remaining three tree groups (initial correction, $\alpha / 3$ ). Results of the sequential Bonferroni technique are displayed for initial significance thresholds of $\alpha=0.05$ and $\alpha=0.10$. Similar appropriate $\alpha$ 

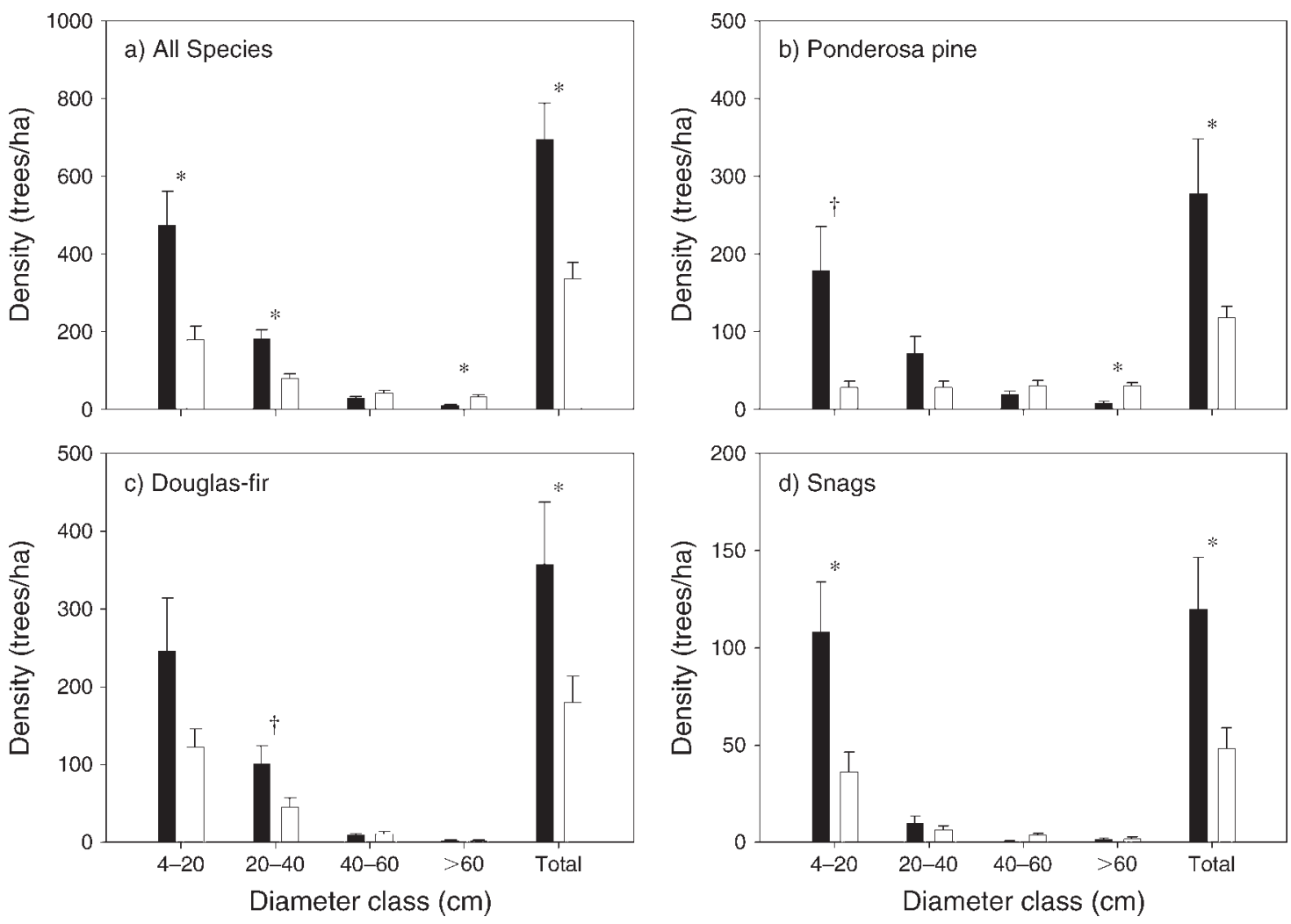

FIg. 2. Diameter class distribution of density for (a) all species, (b) ponderosa pine, (c) Douglas-fir, and (d) snags. Solid bars represent logged sites, and open bars are unlogged sites. A sequential Bonferroni technique was used to establish significance thresholds between all species-size-class comparisons. Statistical significance of differences between logged and unlogged stands within a size class is indicated. Error bars represent + SE.

$* P \leq 0.05 ; \dagger P \leq 0.10$.

adjustments were made for size class comparisons of backcast logged and unlogged stand density and BA.

Independent samples $t$ tests were used to test for density differences by tree groups between unlogged sites from Keeling et al. (2006) and our study. The use of a multivariate linear model for comparisons between burned, unlogged and logged stands from the combined data set (Keeling et al. 2006 and this study) was not feasible due to violation of the MANOVA procedure's requirement for homogeneous covariation between factors (i.e., sphericity). Instead, we used independentsamples $t$ tests to compare total density and density by tree group for both the subset and full analysis between burned stands $(n=6)$, pooled unlogged stands from both studies (subset, $n=14$; full, $n=29$ ), and logged stands from this study (subset, $n=8$; full, $n=23$ ). We used the same tree groups as in the previous analysis except that we replaced the "snags" group with a category incorporating all tree species other than ponderosa pine and Douglas-fir. This change was made because snags were not measured in the Keeling et al. 2006 study as we did and because species other than ponderosa pine and Douglas-fir have been shown to be a significant contributor to changes in stand structure from recently burned to unburned sites (Keeling et al. 2006), whereas we did not find this to be the case between our logged and unlogged sites. For all $t$-tests, variance homogeneity was assessed using Levene's test. We adjusted the $\alpha$-level for multiple comparisons between treatments within each tree group and for the initial $t$ test comparison of unlogged sites from both studies using the sequential Bonferroni technique (initial correction $\alpha / 4$ for each species group). Mann-Whitney non parametric tests were used to compare treatment differences for species other than ponderosa pine and Douglas-fir, for which homogeneity of variance assumptions were not met. Significance results for all tests were conducted for $\alpha=0.05$ and $\alpha=0.10$. Independentsamples $t$ tests were used in comparisons of slope, aspect and elevation between all treatments.

\section{RESUlTS}

Elevation, slope, and aspect were similar $(P>0.20$ for all tests) between logged and unlogged sites (Table 1). With the exception of two sites that were separated by more than $5 \mathrm{~km}$, the average distance between paired sites was $0.15 \mathrm{~km}$, with a range of $0.04-0.31 \mathrm{~km}$ (Table 1). Analysis of increment cores from contemporary large 
TABLE 2. Mean values (with SE reported in parentheses) and range for density and basal area (BA) of ponderosa pine, Douglasfir, all species pooled, and snags by diameter size class.

\begin{tabular}{|c|c|c|c|c|c|c|}
\hline \multirow[b]{2}{*}{ Tree group } & \multicolumn{2}{|c|}{$4-20 \mathrm{~cm}$} & \multicolumn{2}{|c|}{$20-40 \mathrm{~cm}$} & \multicolumn{2}{|c|}{$40-60 \mathrm{~cm}$} \\
\hline & Logged & Unlogged & Logged & Unlogged & Logged & Unlogged \\
\hline \multicolumn{7}{|l|}{ Density (trees/ha) } \\
\hline All species & $\begin{array}{c}473.9^{*}(86.2) \\
0-1380\end{array}$ & $\begin{array}{c}179.6(33.9) \\
0-590\end{array}$ & $\begin{array}{c}182.2^{*}(23.3) \\
0-350\end{array}$ & $\begin{array}{c}80.4(11.6) \\
10-240\end{array}$ & $\begin{array}{c}28.3(5.6) \\
0-110\end{array}$ & $\begin{array}{c}43.0(6.5) \\
0-130\end{array}$ \\
\hline Ponderosa pine & $\begin{array}{c}178.7 \dagger(56.8) \\
0-1070\end{array}$ & $\begin{array}{c}28.7(7.7) \\
0-130\end{array}$ & $\begin{array}{c}72.6(20.9) \\
0-350\end{array}$ & $\begin{array}{c}28.3(7.6) \\
0-160\end{array}$ & $\begin{array}{c}18.7(5.1) \\
0-90\end{array}$ & $\begin{array}{c}30.4(6.5) \\
0-130\end{array}$ \\
\hline Douglas-fir & $\begin{array}{c}245.7(68.7) \\
0-1230\end{array}$ & $\begin{array}{c}122.2(24.2) \\
0-430\end{array}$ & $\begin{array}{c}101.3 \dagger(22.5) \\
0-300\end{array}$ & $\begin{array}{c}45.7(11.5) \\
0-230\end{array}$ & $\begin{array}{c}8.7(2.2) \\
0-40\end{array}$ & $\begin{array}{c}10.4(3.0) \\
0-30\end{array}$ \\
\hline Snags & $\begin{array}{c}108.3^{*}(25.6) \\
0-450\end{array}$ & $\begin{array}{c}36.5(9.9) \\
0-190\end{array}$ & $\begin{array}{c}10(3.3) \\
0-60\end{array}$ & $\begin{array}{c}6.5(1.7) \\
0-30\end{array}$ & $\begin{array}{c}0.4 \S(0.4) \\
0-10\end{array}$ & $\begin{array}{c}3.5(1.0) \\
0-10\end{array}$ \\
\hline \multicolumn{7}{|l|}{ Basal area $\left(\mathrm{m}^{2} / \mathrm{ha}\right)$} \\
\hline All species & $\begin{array}{c}4.72 *(0.82) \\
0-13.67\end{array}$ & $\begin{array}{c}1.81(0.36) \\
0-6.84\end{array}$ & $\begin{array}{c}11.69 *(1.50) \\
0-23.32\end{array}$ & $\begin{array}{l}5.37(0.69) \\
0.32-14.73\end{array}$ & $\begin{array}{c}5.05(1.02) \\
0-21.77\end{array}$ & $\begin{array}{c}8.28(1.34) \\
0-27.33\end{array}$ \\
\hline Ponderosa pine & $\begin{array}{c}1.97 \dagger(0.62) \\
0-10.99\end{array}$ & $\begin{array}{c}0.30(0.09) \\
0-1.54\end{array}$ & $\begin{array}{c}4.77(1.40) \\
0-20.41\end{array}$ & $\begin{array}{c}2.17(0.56) \\
0-11.42\end{array}$ & $\begin{array}{c}3.36(0.96) \\
0-18.35\end{array}$ & $\begin{array}{c}6.00(1.31) \\
0-27.33\end{array}$ \\
\hline Douglas-fir & $\begin{array}{c}2.37(0.64) \\
0-11.57\end{array}$ & $\begin{array}{c}1.26(0.29) \\
0-5.09\end{array}$ & $\begin{array}{c}6.38 * \dagger(1.38) \\
0-19.59\end{array}$ & $\begin{array}{c}2.82(0.69) \\
0-14.32\end{array}$ & $\begin{array}{c}1.58(0.37) \\
0-5.88\end{array}$ & $\begin{array}{c}1.85(0.58) \\
0-7.81\end{array}$ \\
\hline Snags & $\begin{array}{c}0.63^{*}(0.15) \\
0-2.32\end{array}$ & $\begin{array}{c}0.26(0.08) \\
0-1.41\end{array}$ & $\begin{array}{c}0.53(0.16) \\
0-2.62\end{array}$ & $\begin{array}{c}0.39(0.11) \\
0-1.65\end{array}$ & $\begin{array}{c}0.09 \S(0.09) \\
0-2.01\end{array}$ & $\begin{array}{c}0.07(0.22) \\
0-2.79\end{array}$ \\
\hline
\end{tabular}

Notes: The percentage of total density and basal area composed of trees $<40 \mathrm{~cm}$ dbh is calculated for each row. Boldface type indicates $P \leq 0.05$. The symbols " $\uparrow "$ and "*" in the Logged column indicate comparisons within a size-class-tree-group combination that met Bonferroni adjusted significance thresholds at $\alpha=0.10$ and $\alpha=0.05$, respectively.

$\ddagger$ Nonparametric Wilcoxon signed rank test.

$\S$ Values were ln-transformed.

trees $\geq 40 \mathrm{~cm}$ dbh in logged and unlogged sites (C. Naficy, unpublished data) found no significant differences in the age of large trees between paired sites $(P>$ $0.05)$. Likewise, no significant differences were found for backcast density and BA of trees for all size classes in logged and unlogged sites prior to logging $(P>0.05$ for all tests). Logging reconstructions indicated that all logged sites experienced removal of many medium and large overstory trees (average reconstructed dbh of trees harvested $=49 \mathrm{~cm}$, range $=27-80 \mathrm{~cm}$ ) although a number of large and medium trees remained in most sites (average density of backcast trees $\geq 40 \mathrm{~cm}$ dbh harvested $=72 \%$, range $=0-100 \%$ ). On average, $68 \%$ of backcast basal area (range $=24-100 \%)$ was harvested.
Average total density of logged sites was more than twice that of unlogged sites $(P<0.001$, Fig. 2a, Tables 2 and 3). However, there were no significant differences in total stand basal area $(P=0.096$, Fig. 3a, Tables 2 and $3)$. Omnibus tests from the MANOVA analysis indicated significant differences in the distribution of density and BA across size-class-tree-groups $(P<0.01$ for both density and BA). On average, logged sites had higher total density of trees in all tree groups $(P<0.05$ for all groups, Fig. 2b-d), with higher BA of Douglas-fir $(P<$ $0.05)$ and lower BA of ponderosa pine $(P<0.05$; Fig. 3b, c, Table 2). Average basal area distribution across species shifted from $22.7 \mathrm{~m}^{2} /$ ha ponderosa pine $(74 \%)$ and $6.5 \mathrm{~m}^{2} /$ ha Douglas-fir $(21 \%)$ in unlogged sites to $13.5 \mathrm{~m}^{2} /$ ha ponderosa pine $(52 \%)$ and $11.2 \mathrm{~m}^{2} / \mathrm{ha}$

TABLE 3. $\quad P$ values for paired $t$ test comparisons of density and BA of logged and unlogged stands for ponderosa pine, Douglas-fir, all species combined, and snags by diameter size class and all diameters pooled.

\begin{tabular}{|c|c|c|c|c|c|}
\hline Tree group & $4-20 \mathrm{~cm}$ & $20-40 \mathrm{~cm}$ & $40-60 \mathrm{~cm}$ & $>60 \mathrm{~cm}$ & Total \\
\hline \multicolumn{6}{|l|}{ Density (trees/ha) } \\
\hline All species & $0.000 *$ & $0.000 *$ & 0.129 & $0.001 * \S$ & $0.000 *$ \\
\hline Ponderosa pine & $0.009 \dagger$ & 0.027 & 0.205 & $0.000^{*}$ & $0.025^{*}$ \\
\hline Douglas-fir & 0.040 & $0.009 \dagger$ & 0.657 & $1.00 \ddagger$ & $0.010 *$ \\
\hline Snags & $0.002 *$ & 0.336 & 0.016 & 0.705 & $0.003^{*}$ \\
\hline \multicolumn{6}{|l|}{ Basal area $\left(\mathrm{m}^{2} / \mathrm{ha}\right)$} \\
\hline All species & $0.000^{*}$ & $0.000^{*}$ & 0.093 & $0.000^{*}$ & 0.096 \\
\hline Ponderosa pine & $0.007 \dagger$ & 0.065 & 0.141 & $0.000^{*}$ & $0.014 *$ \\
\hline Douglas-fir & 0.029 & $0.008 \dagger$ & 0.695 & $1.00 \ddagger$ & $0.017 *$ \\
\hline Snags & $0.002 *$ & 0.491 & $0.028 \ddagger$ & $0.612 \ddagger$ & 0.713 \\
\hline
\end{tabular}

Notes: Boldface type indicates $P \leq 0.05$. Comparisons within a size-class-tree-group combination that meet Bonferroni adjusted significance thresholds at $\alpha=0.10$ and $\alpha=0.05$ are indicated by " $\dagger$ " and "*," respectively.

\pm Nonparametric Wilcoxon signed rank test.

$\S$ Values were ln-transformed. 
TABLE 2. Extended.

\begin{tabular}{|c|c|c|c|c|c|}
\hline \multicolumn{2}{|c|}{$>60 \mathrm{~cm}$} & \multicolumn{2}{|c|}{ Total } & \multicolumn{2}{|c|}{ Stems $<40 \mathrm{~cm}(\%)$} \\
\hline Logged & Unlogged & Logged & Unlogged & Logged & Unlogged \\
\hline $\begin{array}{c}10.4^{*}+(2.4) \\
0-40\end{array}$ & $\begin{array}{c}33.5(4.0) \\
0-70\end{array}$ & $\begin{array}{c}694.8^{*}(94.1) \\
0-1700\end{array}$ & $\begin{array}{c}336.5(41.4) \\
40-920\end{array}$ & 94 & 77 \\
\hline $8.3^{*}(2.1)$ & $30.9(4.0)$ & $278.3^{*}(70.0)$ & $118.3(14.2)$ & 90 & 48 \\
\hline $0-40$ & $0-70$ & $0-1280$ & $20-300$ & & \\
\hline $1.7 \S(1.0)$ & $1.7(0.8)$ & $357.4^{*}(80.5)$ & $180.0(34.0)$ & 97 & 93 \\
\hline $0-20$ & $0-10$ & $0-1280$ & $0-690$ & & \\
\hline $1.3 \dagger(0.7)$ & $1.7(0.8)$ & $120.0^{*}(26.5)$ & $48.3(10.7)$ & 99 & 89 \\
\hline $0-10$ & $0-10$ & $0-470$ & 0-200 & & \\
\hline $4.41 *(1.10)$ & $15.13(1.84)$ & $25.87(2.49)$ & $30.59(2.54)$ & 63 & 23 \\
\hline $0-16.76$ & $0-28.34$ & $0-53.88$ & $7.92-59.8$ & & \\
\hline $3.43^{*}(0.91)$ & $14.24(1.83)$ & $13.52 *(2.44)$ & 22.70 & 50 & 11 \\
\hline 0-14.71 & $0-28.14$ & $0-42.42$ & $7.92-57.43$ & & \\
\hline $0.86 \S(0.60)$ & $0.59(0.28)$ & $11.19 *(2.12)$ & $6.52(1.25)$ & 78 & 63 \\
\hline $0-13.33$ & $0-4.42$ & 0-28.53 & $0-23.73$ & & \\
\hline $0.65 \S(0.41)$ & $0.78(0.02)$ & $1.90(0.47)$ & $2.14(0.42)$ & 61 & 30 \\
\hline $0-8.59$ & $0-7.01$ & $0-8.61$ & $0-7.32$ & & \\
\hline
\end{tabular}

Douglas-fir (43\%) in logged sites (Table 2). Stand density and BA increases in logged vs. unlogged stands were mainly due to trees $<40 \mathrm{~cm}$ dbh (Figs. $2 \mathrm{a}-\mathrm{c}, 3 \mathrm{a}-\mathrm{c}$, Table 2), although once adjusted for multiple comparisons only ponderosa pine $4-20 \mathrm{~cm}$ dbh and Douglas-fir 20-40 cm dbh were significant at $P<0.10$ (Fig. 2b, c, Table 3 ). In contrast, the density and BA of large ( $\mathrm{dbh} \geq$ $60 \mathrm{~cm}$ ) trees was significantly lower in logged stands relative to unlogged stands ( $P \leq 0.001$ for both density and BA, Table 3 ), due to a paucity of large ponderosa pine trees $(P<0.001$, Figs. $2 b, 3 b)$. In combination, the lack of large trees and abundance of trees $<40 \mathrm{~cm}$ dbh in logged stands, resulted in strong dominance of small fire-intolerant trees in overall stand characteristics (Table 2) of logged sites. In contrast, there was a more even distribution of ponderosa pine tree density across all size classes in unlogged stands (Fig. 2b), with a larger proportion of stand BA and density contributed by firetolerant ponderosa pine trees $\geq 40 \mathrm{~cm}$ dbh (Table 2). However, in both logged and unlogged stands the relative proportion of total Douglas-fir density comprised of trees $<40 \mathrm{~cm}$ dbh was similar (Table 2), likely a result of their shared history of fire exclusion. The total density of snags was significantly higher in logged stands than in unlogged stands $(P<0.01$, Tables 2 and 3$)$, due to significantly higher numbers of small snags $(P<0.01$, Fig. 2d). Although not significantly different once adjusted for multiple comparisons, snags $40-60 \mathrm{~cm}$ dbh tended to be slightly more frequent in unlogged than logged sites (Table 2).

Comparisons of physiographic site variables from Keeling et al. (2006) and this study showed no differences in average elevation or aspect $(P>0.05)$, but mean slope of sites from Keeling et al. (2006) was greater than in our sites $(P<0.01$, Table 1$)$. However, total density and density by tree group between unlogged stands from Keeling et al. (2006) and our study were not statistically different for either the subset or the full analysis (Table 4, Fig. 4a, b) and were pooled in all subsequent analysis. Relative to burned stands, average total stand density was approximately twofold higher in stands subjected to fire exclusion alone for both the subset and full analysis (Fig. 4a, b). However, once corrected for multiple comparisons these differences were not statistically significant in either analysis, except for significant increases of Douglas-fir density at $\alpha=0.1$ in the subset analysis (Table 4). In contrast, relative to burned stands, average stand density in logged stands was over threefold (full data set) and almost fourfold (subset) higher $(P<0.01$, Fig. 4a, b). Total, ponderosa pine and Douglas-fir density was higher in logged relative to unlogged stands in the full analysis, while in the subset analyses differences were apparent for total and Douglas-fir density. However, once corrected for multiple comparisons, only differences for total density in the full analysis $(P<0.01)$ and for Douglas-fir density in the subset analysis $(P<0.05)$ were significant (Fig. 4a, b; Table 4). Lower statistical significance of differences in average total density between burned and unlogged sites in both analyses and between unlogged and logged sites in the subset analysis (Table 4) likely reflect the lack of pairing in the combined data set. Average density of species other than ponderosa pine and Douglas-fir was higher in unlogged and logged sites relative to burned sites (Fig. 4), although differences were not statistically significant (Table 4) due to high variability in their presence and abundance.

\section{Discussion And Conclusions}

We show that historically logged, fire-excluded ponderosa pine forests of the northern Rocky Mountains 

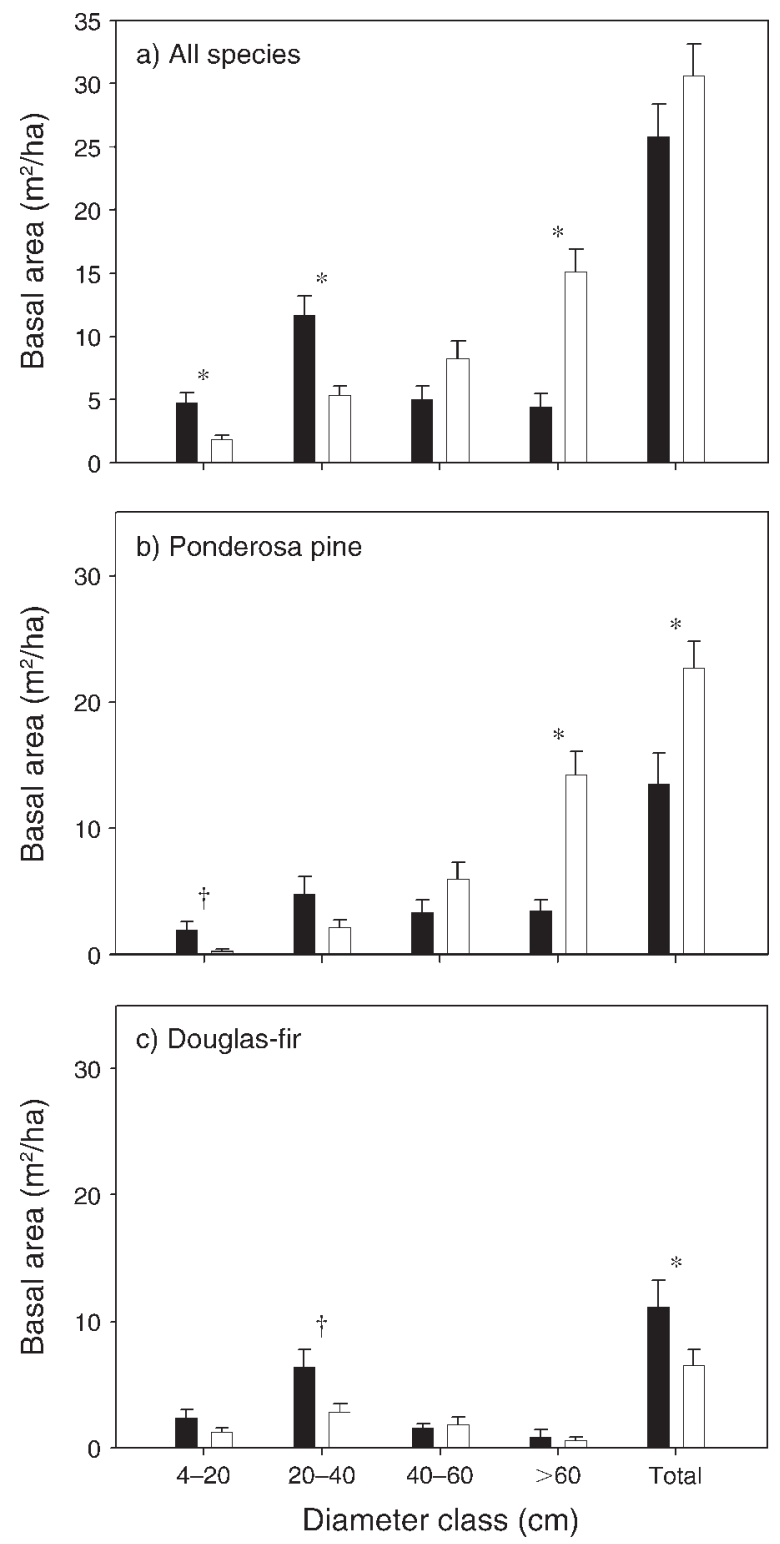

FIG. 3. Diameter class distribution of basal area for (a) all species, (b) ponderosa pine, and (c) Douglas-fir. Filled bars represent logged sites, and open bars are unlogged sites. A sequential Bonferroni technique was used to establish significance thresholds between all species-size-class comparisons. Differences between logged and unlogged stands within a size class are indicated. Error bars represent $+\mathrm{SE}$.

$* P \leq 0.05 ; \dagger P \leq 0.10$.

have more homogeneous stand structure, much higher average stand density, more standing dead trees and greater numbers and dominance of small, fire-intolerant trees than their unlogged, fire-excluded counterparts (Fig. 2a-d, Fig. 3a-c, Table 2). Furthermore, the interactive effects of logging and fire exclusion on stand density substantially exceed those due to fire exclusion alone (Fig. 4a, b). Although lack of pairing in the combined data set analysis reduced somewhat the statistical significance of cross-treatment comparisons relative to the respective paired analyses (see Results and Keeling et al. 2006), the similar results between the full data set and the subset analyses support the generality of our results for ponderosa pine/Douglas-fir forests across a broad area within the northern Rockies (Fig. 1). While fire exclusion has led to increased average forest density and abundance of fire-intolerant tree species in some semiarid forests of the western United Sates (Minnich et al. 1995, Fulé et al. 2002, Keeling et al. 2006, Goforth and Minnich 2008), the rate and magnitude of this change are quite variable (Keeling et al. 2006). Our results from a relatively large geographical area show that historical logging has generally exacerbated these changes such that logged forests now bear little resemblance either to modern unlogged, fire-excluded forests or to contemporary, fire-maintained counterparts (Fig. 4a, b). Overall, our results reiterate the need to account for the long-term effects of multiple perturbations (in this case, historical logging and fire exclusion) to understand contemporary forest structure (Paine et al. 1998).

It is unclear how differences in the current structure and composition of previously logged and unlogged ponderosa pine/Douglas-fir forests will affect stand- and landscape-scale dynamics in these systems on longer time scales than we have studied here. However, given the importance of disturbances in these forests, future stand characteristics will likely be dependent on interactions with and recovery from future natural disturbances. Our results suggest that, to the extent that modern wildfires are driven by vegetation and fuel characteristics, historically logged stands are likely more prone to severe, stand-replacing wildfires than unlogged, fire-excluded stands. Such prediction is based on the strong increases in total stand density, the abundance of smaller, less fire-tolerant tree species which serve as ladder fuels and reduce crown to base height, the increased homogeneity of forest structure, and the increase of dead trees that we have documented in logged sites (Figs. 2 and 3). Furthermore, the abundance of residual logging slash often generated by historical timber harvest produces higher flame lengths and more intense surface fires that can increase the probability of crown fire initiation (Dodge 1972, Steele et al. 1986, Agee 1993, Skinner and Chang 1996, Hessburg and Agee 2003, Stephens and Moghaddas 2005). This prediction is consistent with reports of uncharacteristically severe fires in contemporary, previously logged forests in the northern Rockies and elsewhere in the western United States (Dodge 1972, Steele et al. 1986, Agee 1993, Weatherspoon and Skinner 1995, Skinner and Chang 1996, Odion et al. 2004, Baker et al. 2007). In contrast, modern wildfires in many unlogged, fireexcluded semiarid forests continue to exhibit predominantly low- and medium-severity burns (Brown et al. 1994, Odion and Hanson 2006, 2008, Collins and Stephens 2007, Collins et al. 2007, Fulé and Laughlin 
TABLE 4. $\quad P$ values for independent samples $t$ tests of tree density of burned, unlogged, and logged sites from this study and those of Keeling et al. (2006).

\begin{tabular}{|c|c|c|c|c|}
\hline Tree group & Burned vs. unlogged & Burned vs. logged & Unlogged vs. logged & $\begin{array}{c}\text { Unlogged }(\mathrm{K}) \\
\text { vs. unlogged }(\mathrm{N})\end{array}$ \\
\hline \multicolumn{5}{|l|}{ Subset } \\
\hline All species & 0.047 & $0.007 *$ & 0.049 & 0.671 \\
\hline Ponderosa pine & 0.363 & 0.388 & 0.058 & 0.178 \\
\hline Douglas-fir & $0.021 \dagger$ & $0.018 \dagger$ & $0.049 \dagger$ & 0.422 \\
\hline Other & 0.051 & 0.147 & 0.889 & 0.370 \\
\hline \multicolumn{5}{|l|}{ Full set } \\
\hline All species & 0.101 & $<0.001 *$ & $0.003 *$ & 0.163 \\
\hline Ponderosa pine & 0.395 & 0.375 & 0.039 & 0.744 \\
\hline Douglas-fir & 0.066 & $0.001 *$ & 0.049 & 0.858 \\
\hline Other & $0.235 t$ & $0.212 \ddagger$ & $0.910 \ddagger$ & $0.414 \ddagger$ \\
\hline
\end{tabular}

Notes: The final column refers to comparisons made between unlogged sites of Keeling et al. (2006) (K) and this study (N). Boldface type indicates $P \leq 0.05$. Comparisons meet Bonferroni adjusted significance thresholds when followed by " $\uparrow$ " for $\alpha=0.10$ and "*" for $\alpha=0.05$. To ensure the validity of combining the two data sets, we tested whether fire-excluded, unlogged sites from both studies were similar, and we compared results using the whole data set from our study $(n=23)$ with those using only a subset $(n=8)$ of our sites nearby the areas studied by Keeling et al. (2006).

$\ddagger$ Mann Whitney $U$ test.

2007, Holden et al. 2007, Safford et al. 2008; but see Goforth and Minnich 2008). High stand density and BA have also been consistently associated with greater susceptibility to widespread, high-severity insect outbreaks (Negron and Popp 2004, Fettig et al. 2007). Given the extensive history of logging in semiarid forests across the western United States (Veblen and Lorenz 1986, Habeck 1988, Arno et al. 1995, Minnich et al. 1995, Fulé et al. 2002, Hessburg and Agee 2003, Baker et al. 2007) these findings highlight significant ecological, social, and economic costs resulting from past timber harvest that have been poorly recognized and frequently ascribed disproportionately to fire exclusion alone.

Similar to substantial regional variation in fire regimes and fire exclusion effects in semiarid western forests (Minnich et al. 1995, McKenzie et al. 2000, Fulé et al. 2002, Schoennagel et al. 2004, Keeling et al. 2006, Goforth and Minnich 2008), the effects of the interaction between historical logging and fire exclusion may also vary across broad geographic regions. For example, limited data from southwestern ponderosa pine forests suggest that historical logging may not produce such strong long-term density feedbacks as we have documented in the northern Rockies (Fulé et al. 2002). In contrast, and similar to our results, apparent increases in stand density of logged, fireexcluded areas relative to unlogged, fire-excluded areas of ponderosa pine forest have been reported in the Rocky Mountains of Colorado (Kaufmann et al. 2000) and in southern California's San Bernardino Mountains (Minnich et al. 1995). It is also important to note that long-term responses to timber harvest are likely sensitive to differences in the specific nature and intensity of silvicultural treatments. Our results are specific to singleentry individual selection and small group selection harvest of medium and large trees, as was common during the early 20th century in the Inland and Pacific Northwest (Gruell et al. 1982, Smith and Arno 1999, Hessburg and Agee 2003) and many other regions (Veblen and Lorenz
1986, Minnich et al. 1995, Kaufmann et al. 2000). Further examination of long-term responses to different silvicultural treatments or repeated harvests is needed.

There are notable implications of our results for restoration and fuel reduction strategies in semi-arid forests of the northern Rockies. First, historically logged ponderosa pine forests in the northern Rocky Mountains have experienced greater departures from reference conditions than unlogged, fire-excluded forests. The current forest structure and composition that we have documented in logged forests suggests that, where fuel reduction goals are primary, these forests should constitute a clear priority. Emphasizing fuel reduction treatments in previously logged forests, especially near communities and existing road infrastructure where long-term treatment monitoring and maintenance is most feasible, will also help maximize their efficiency and economy. Although specific management prescriptions ultimately need to consider site-specific conditions, our results suggest that while previously logged, fireexcluded forests may benefit from significant mechanical stand manipulations before fire can be safely introduced, unlogged, fire-excluded forests may require much less invasive treatments. This is consistent with growing evidence that labor intensive and costly mechanical treatments in many unlogged, fire-excluded forests may not be necessary to restore wildfire despite structural departures from historical conditions (Brown et al. 1994, Odion and Hanson 2006, 2008, Collins and Stephens 2007, Collins et al. 2007, Fulé and Laughlin 2007, Holden et al. 2007, Safford et al. 2008; but see Goforth and Minnich 2008).

Second, our results point to potential long-term risks associated with mechanical treatments, especially in previously unlogged forests. While modern fuel reduction or restoration techniques certainly differ from historical logging practices in many ways, there are also some important similarities. As opposed to historical 

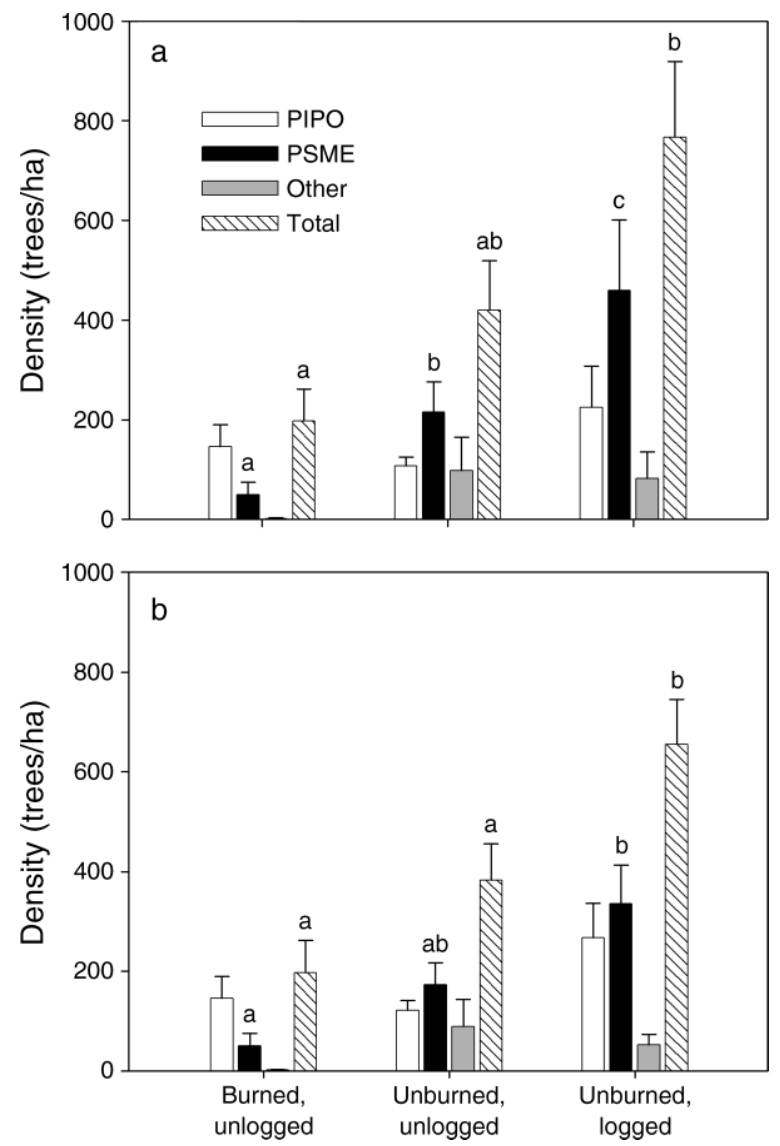

FIG. 4. Combined data from Keeling et al. (2006) and our study showing tree density for ponderosa pine (PIPO), Douglas-fir (PSME), other tree species, and all species pooled for unlogged fire-maintained stands, unlogged fire-excluded stands, and logged fire-excluded stands. Results are displayed for (a) the regional subset analysis and (b) the full analysis. Within a tree group, bars with different letters across treatments are statistically significantly different at $\alpha=0.10$, once corrected for multiple comparisons with the sequential Bonferroni technique. Actual $P$ values are listed in Table 4. Values for all variables in unburned, unlogged stands from Keeling et al. (2006) and this study were not statistically different and were pooled. Values for burned, unlogged and unburned, logged sites come from Keeling et al. (2006) and this study, respectively. Error bars represent $+\mathrm{SE}$.

timber harvest, current silvicultural practices emphasize slash treatment and retention of more large, fire-tolerant trees. However, both involve soil disturbance and reduction of canopy cover. Furthermore, some modern fuel reduction methods specifically recommend removal of medium and some large overstory trees in order to increase canopy spacing and reduce crown fire spread (Graham et al. 1999, Agee and Skinner 2005, Raymond and Peterson 2005). Others benefit from the harvest of medium or large, commercially valuable trees to help minimize treatment costs (North et al. 2007, Hartsough et al. 2008). While there is a significant body of modeling work which predicts short-term alteration of fire behavior associated with such treatments (Graham et al. 1999, Agee and Skinner 2005), their effects under different long-term fuels management scenarios, or if treatments are not well maintained, have not been thoroughly evaluated. As a result, the extent to which modern mechanical treatments could have similar longterm counterproductive effects to those reported here for historically logged sites when treated stands are left unattended is largely still unknown. Results from one of the few existing modeling studies of multi-decadal landscape response to various contemporary fuels management scenarios corroborate the potential risks of increased fire hazard following silvicultural treatments that we allude to here, if treatments are not maintained (Ager et al. 2007). Relative to untreated stands, Ager et al. (2007) found that thinned and burned stands left subsequently untreated developed similar or higher crown bulk density and lower canopy base height and crowning index, all characteristics associated with high fire hazard and consistent with the long-term trends suggested by our results from historically logged sites.

It is important to emphasize that our intent is not to make direct inferences of the effects of contemporary treatments from historical logging, but rather to highlight the lack of data on long-term effects of various modern silvicultural practices. Such lack of scientific evidence incorporates a fundamental element of risk, particularly if recurrent fire is not effectively restored to fire-prone ecosystems or substituted by other means of long-term fuels management. The successful reintroduction of fire is contingent on the long-term commitment of financial resources and consistent management policy that promotes a greater use of prescribed and wildland fire on a landscape (i.e., greater than stand-level) scale. Currently, where over half of the Forest Service budget is spent on fire suppression and other wildfire-related activities and $97-99 \%$ of all fires continue to be purposefully extinguished (Kauffman 2004, Stephens and Ruth 2005), it is apparent that neither the financial resources nor the policy imperatives for such a commitment have yet been put in place. Where allowance of natural wildfires is infeasible and alternative fuel treatments (e.g., mechanical thinning) are deemed necessary, their potential negative impacts on future forest conditions, wildlife habitat, and other values should not be ignored (Wales et al. 2007). Clearly, there is a need for careful consideration of the long-term effects of modern silvicultural treatments as part of a forward-looking fuels management approach that balances fire hazard reduction with wildlife habitat needs and other ecological values and is commensurate with the realistic financial and institutional ability of public land management agencies to maintain such treatments over time.

\section{ACKNOWLEDGMENTS}

This research was funded by a Science Grant from the Yellowstone to Yukon Conservation Initiative to A. Sala and the WildWest Institute. Funding from USDA NRICG 200235107-12267 and from the Aldo Leopold Wilderness research 
Institute (USDA FS RMRS-ALWRI 4901) allowed sampling in remote frequently burned stands. We thank the many Forest Service employees who helped us locate study sites, Greg Peters for his dedication to intensive fieldwork, and Geoff Farinholt for help with lab work. We also thank three anonymous reviewers for their thorough reviews and helpful comments.

\section{Literature Cited}

Agee, J. K. 1993. Fire ecology of Pacific Northwest forests. Island Press, Washington, D.C., USA.

Agee, J. K., and C. N. Skinner. 2005. Basic principles of forest fuel reduction treatments. Forest Ecology and Management 211:83-96.

Ager, A. A., A. J. McMahan, J. J. Barrett, and C. W. McHugh. 2007. A simulation study of thinning and fuel treatments on a wildland-urban interface in eastern Oregon, USA. Landscape and Urban Planning 80:292-300.

Allen, C. D., M. Savage, D. A. Falk, K. F. Suckling, T. W. Swetnam, T. Schulke, P. B. Stacey, P. Morgan, M. Hoffman, and J. T. Klingel. 2002. Ecological restoration of Southwestern ponderosa pine ecosystems: a broad perspective. Ecological Applications 12:1418-1433.

Arno, S. F., and J. K. Brown. 1989. Managing fire in our forest: time for a new initiative. Journal of Forestry 87:44-46.

Arno, S. F., D. J. Parsons, and R. E. Keane. 2000. Mixedseverity fire regimes in the Northern Rocky Mountains: consequences of fire exclusion and options for the future. Pages 225-232 in D. N. Cole, S. F. McCool, W. T. Borrie, and J. O'Loughlin, compilers. Wilderness science in a time of change conference. Volume 5. Wilderness ecosystems, threats and management. USDA Forest Service Proceedings RMRSP-15-VOL-5. USDA Forest Service Rocky Mountain Research Station, Fort Collins, Colorado, USA.

Arno, S. F., J. H. Scott, and M. G. Hartwell. 1995. Age-class structure of old growth ponderosa pine/Douglas-fir stands and its relationship to fire history. INT RP-481. USDA Forest Service, Intermountain Research Station, Ogden, Utah, USA.

Arno, S. F., H. Y. Smith, and M. A. Krebs. 1997. Old growth ponderosa pine and western larch stand structures: Influences of pre-1900 fires and fire exclusion. INT RP-495. USDA Forest Service, Intermountain Research Station, Ogden, Utah, USA.

Baker, W. L., T. T. Veblen, and R. L. Sherriff. 2007. Fire, fuels and restoration of ponderosa pine-Douglas fir forests in the Rocky Mountains, USA. Journal of Biogeography 34:251269.

Bonnicksen, T. M. 1989. Nature vs. management: fire is not a management value. Journal of Forestry 87:41-43.

Brown, J. K., S. F. Arno, S. W. Barrett, and J. P. Menakis. 1994. Comparing the prescribed natural fire program with presettlement fires in the Selway-Bitteroot Wilderness. International Journal of Wildland Fire 4:157-168.

Brown, R. T., J. K. Agee, and J. F. Franklin. 2004. Forest restoration and fire: principles in the context of place. Conservation Biology 18:903-912.

Collins, B. M., M. Kelly, J. W. van Wagtendonk, and S. L. Stephens. 2007. Spatial patterns of large natural fires in Sierra Nevada wilderness areas. Landscape Ecology 22:545557.

Collins, B. M., and S. L. Stephens. 2007. Managing natural wildfires in Sierra Nevada wilderness areas. Frontiers in Ecology and the Environment 5:523-527.

Covington, W. W. 2000. Helping Western forests heal: the prognosis is poor for U.S. forest ecosystems. Nature 408:135136.

Dodge, M. 1972. Forest fuel accumulation: a growing problem. Science 177:139-142.

Fettig, C. J., K. D. Klepzig, R. F. Billings, A. S. Munson, T. E. Nebeker, J. F. Negron, and J. T. Nowak. 2007. The effectiveness of vegetation management practices for preven- tion and control of bark beetle infestations in coniferous forests of the western and southern United States. Forest Ecology and Management 238:24-53.

Fulé, P. Z., W. W. Covington, M. M. Moore, T. A. Heinlein, and A. E. M. Waltz. 2002. Natural variability in forests of the Grand Canyon, USA. Journal of Biogeography 29:31-47.

Fulé, P. Z., and D. C. Laughlin. 2007. Wildland fire effects on forest structure over an altitudinal gradient, Grand Canyon National Park, USA. Journal of Applied Ecology 44:136146.

Goforth, B. R., and R. A. Minnich. 2008. Densification, standreplacement wildfire, and extirpation of mixed conifer forest in Cuyamaca Rancho State Park, southern California. Forest Ecology and Management 256:36-45.

Graham, R. T., A. E. Harvey, T. B. Jain, and J. R. Tonn. 1999. The effects of thinning and similar stand treatments on fire behavior in western forests. USDA Forest Service PNW GTR-463. Pacific Northwest Research Station, Portland, Oregon, USA.

Graham, R. T., S. McCaffrey, and T. B. Jain. 2004. Science basis for changing forest structure to modify wildfire behavior and severity. RMRS GTR-120. USDA Forest Service, Rocky Mountain Research Station, Fort Collins, Colorado, USA.

Gruell, G. E., W. C. Schmidt, S. F. Arno, and W. J. Reich. 1982. Seventy years of vegetative change in a managed ponderosa pine forest in western Montana: implications for resource management. INT GTR-130. USDA Forest Service, Intermountain Forest and Range Experiment Station, Ogden, Utah, USA.

Habeck, J. R. 1988. Old-growth forests in the Northern Rocky Mountains. Natural Areas Journal 8:202-211.

Habeck, J. R. 1990. Old-growth ponderosa pine-western larch forests in western Montana: ecology and management. Northwest Environmental Journal 6:273-292.

Hartsough, B. R., S. Abrams, R. J. Barbour, E. S. Drews, J. D. McIver, J. J. Moghaddas, D. W. Schwilk, and S. L. Stephens. 2008. The economics of alternative fuel reduction treatments in western United States dry forests: financial and policy implications from the national Fire and Fire Surrogate study. Forest Policy and Economics 10:344-354.

Hessburg, P. F., and J. K. Agee. 2003. An environmental narrative of Inland Northwest United States forests, 1800 2000. Forest Ecology and Management 178:23-59.

Hessburg, P. F., R. B. Salter, and K. M. James. 2007. Reexamining fire severity relations in pre-management era mixed conifer forests: inferences from landscape patterns of forest structure. Landscape Ecology 22:5-24.

Hessburg, P. F., B. G. Smith, R. B. Salter, R. D. Ottmar, and E. Alvarado. 2000. Recent changes (1930s-1990s) in spatial patterns of interior northwest forests, USA. Forest Ecology and Management 136:53-83.

Heyerdahl, E. K., P. Morgan, and J. P. I. Riser. 2008. Crossdated fire histories (1650-1900) from ponderosa pinedominated forests of Idaho and western Montana. RMRS GTR-214. USDA Forest Service, Rocky Mountain Research Lab, Fort Collins, Colorado, USA.

HFRA. 2003. Healthy Forests Restoration Act of 2003. 〈http:// frwebgate.access.gpo.gov/cgi-bin/getdoc.cgi?dbname $=108$ cong_bills\&docid=f:h1904enr.txt.pdf $\rangle$

Holden, Z. A., P. Morgan, M. G. Rollins, and K. Kavanagh. 2007. Effects of multiple wildland fires on ponderosa pine stand structure in two southwestern wilderness areas, USA. Fire Ecology 3:18-33.

Kauffman, J. B. 2004. Death rides the forest: perceptions of fire, land use, and ecological restoration of western forests. Conservation Biology 18:878-882.

Kaufmann, M. R., C. M. Regan, and P. M. Brown. 2000. Heterogeneity in ponderosa pine/Douglas-fir forests: age and size structure in unlogged and logged landscapes of central Colorado. Canadian Journal of Forest Research 30:698-711. 
Keeling, E. G., A. Sala, and T. H. DeLuca. 2006. Effects of fire exclusion on forest structure and composition in unlogged ponderosa pine/Douglas-fir forests. Forest Ecology and Management 237:418-428.

McKenzie, D., D. L. Peterson, and J. K. Agee. 2000. Fire frequency in the interior Columbia River Basin: building regional models from fire history data. Ecological Applications 10:1497-1516.

Minnich, R. A., M. G. Barbour, J. H. Burk, and R. F. Fernau. 1995. 60 years of change in Californian conifer forests of the San-Bernardino Mountains. Conservation Biology 9:902914.

Morgan, P., E. K. Heyerdahl, and C. E. Gibson. 2008. Multiseason climate synchronized forest fires throughout the 20th century, northern Rockies, USA. Ecology 89:717-728.

Negron, J. F., and J. B. Popp. 2004. Probability of ponderosa pine infestation by mountain pine beetle in the Colorado Front Range. Forest Ecology and Management 191:17-27.

North, M., J. Innes, and H. Zald. 2007. Comparison of thinning and prescribed fire restoration treatments to Sierran mixedconifer historic conditions. Canadian Journal of Forest Research 37:331-342.

Odion, D. C., E. J. Frost, J. R. Strittholt, H. Jiang, D. A. Dellasala, and M. A. Moritz. 2004. Patterns of fire severity and forest conditions in the western Klamath Mountains, California. Conservation Biology 18:927-936.

Odion, D. C., and C. T. Hanson. 2006. Fire severity in conifer forests of the Sierra Nevada, California. Ecosystems 9:11771189.

Odion, D. C., and C. T. Hanson. 2008. Fire severity in the Sierra Nevada revisited: conclusions robust to further analysis. Ecosystems 11:12-15.

Paine, R. T., M. J. Tegner, and E. A. Johnson. 1998. Compounded perturbations yield ecological surprises. Ecosystems 1:535-545.

Pfister, R. D., B. L. Kovalchik, S. F. Arno, and R. C. Presby. 1977. Forest habitat types of Montana. USFS INT GTR-34. USDA Forest Service, Intermountain Forest and Range Experiment Station, Ogden, Utah, USA.

Raymond, C. L., and D. L. Peterson. 2005. Fuel treatments alter the effects of wildfire in a mixed-evergreen forest, Oregon, USA. Canadian Journal of Forest Research 35: 2981-2995.

Rice, W. R. 1989. Analyzing tables of statistical tests. Evolution 43:223-225.

Safford, H. D., J. Miller, D. Schmidt, B. Roath, and A. Parsons. 2008. BAER soil burn severity maps do not measure fire effects to vegetation: a comment on Odion and Hanson (2006). Ecosystems 11:1-11.

Savage, M., and J. N. Mast. 2005. How resilient are southwestern ponderosa pine forests after crown fires? Canadian Journal of Forest Research 35:967-977.
Schoennagel, T., T. T. Veblen, and W. H. Romme. 2004. The interaction of fire, fuels, and climate across Rocky Mountain forests. BioScience 54:661-676.

Sherriff, R. L., and T. T. Veblen. 2007. A spatially-explicit reconstruction of historical fire occurrence in the ponderosa pine zone of the Colorado Front Range. Ecosystems 10:311323.

Skinner, C. N., and C. Chang. 1996. Fire regimes, past and present. Sierra Nevada Ecosystem Project. Final report to Congress, volume II. Assessments and scientific basis for management options. University of California, Centers for Water and Wildland Resources, Davis, California, USA.

Smith, H. Y., and S. F. Arno. 1999. Eighty-eight years of change in a managed ponderosa pine forest. RMRS GTR-23. USDA Forest Service, Rocky Mountain Research Station, Fort Collins, Colorado, USA.

Steele, R., S. F. Arno, and K. Geier-Hayes. 1986. Wildfire patterns change in central Idaho's ponderosa pine-Douglasfir forest. Western Journal of Applied Forestry 1:16-18.

Steele, R. S., R. D. Pfister, R. A. Ryker, and J. A. Kittams. 1981. Forest habitat types of central Idaho. USFS INT GTR114. USDA Forest Service, Intermountain Forest and Range Experiment Station, Ogden, Utah, USA.

Stephens, S. L., and J. J. Moghaddas. 2005. Silvicultural and reserve impacts on potential fire behavior and forest conservation: twenty-five years of experience from Sierra Nevada mixed conifer forests. Biological Conservation 125: 369-379.

Stephens, S. L., and L. W. Ruth. 2005. Federal forest-fire policy in the United States. Ecological Applications 15:532-542.

Stokes, M. A., and T. L. Smiley. 1968. An introduction to treering dating. University Arizona Press, Tucson, Arizona, USA.

Ten Year Comprehensive Strategy. 2001. Ten year comprehensive strategy of 2001. 〈http://www.forestsandrangelands.gov/ plan/documents/7-19-en.pdf $\rangle$

USGS. 1999. Digital representation of "Atlas of United States Trees" by Elbert L. Little, Jr. Digital Version 1.0. United States Geological Survey. 〈http://esp.cr.usgs.gov/data/atlas/ little/>

Veblen, T. T., and D. C. Lorenz. 1986. Anthropogenic disturbance and recovery patterns in montane forests, Colorado Front Range. Physical Geography 7:1-24.

Wales, B. C., L. H. Suring, and M. A. Hemstrom. 2007. Modeling potential outcomes of fire and fuel management scenarios on the structure of forested habitats in northeast Oregon, USA. Landscape and Urban Planning 80:223-236.

Weatherspoon, C. P., and C. N. Skinner. 1995. An assessment of factors associated with damage to tree crowns from the 1987 wildfires in northern California. Forest Science 41:430451.

White House. 2002. Healthy forests: an initiative for wildfire prevention and stronger communities. 〈http:// georgewbush-whitehouse.archives.gov/infocus/healthyforests/ Healthy_Forests_v2.pdf $>$ 